\title{
Analysis on the correlation between SEO and the performance of listed real estate companies in China
}

\author{
Weihong Huang ${ }^{1,}$, Wei Lin $^{2}$ \\ ${ }^{1}$ School of Economics and Management, Fuzhou University, 350108, China \\ ${ }^{2}$ School of Economics and Management, Fuzhou University, 350108, China \\ *weihongh1989@163.com
}

\begin{abstract}
Seasoned equity offering is one of the important funds sources of listed real estate company, there is significant correlation between the different factors in the seasoned equity offering and real estate listed company's performance after refinancing. The empirical study of 44 sample companies show that in the year of seasoned equity offering, capital structure after financing have significant impact on company performance; in the second year of financing, the overall factors have a most significant impact the performance; In the third year of refinancing, only capital structure can influence the company performance. The financing scale can only have impact on the company's performance in a short-term after seasoned equity offering, the capital structure has a more lasting and stable impact on company performance than other factors.
\end{abstract}

Keywords: Seasoned equity offering, Real estate listed real estate company, Company performance, Correlation.

\section{Introduction}

After China's reform and opening up, China began to market-oriented housing construction, in the 1990s, China fully implemented housing reform, consider the real estate industry "as a new economic growth point". With a series of housing mortgage loan policy published, the real estate industry played a more important role economic growth. In nearly a decade, the explosive growth of the real estate market in China simulated the real estate company to expand fast. Expansion of real estate companies requires a large number of external financing support, seasoned equity offering is an important access for financing support of the real estate listed companies.

According to the capital structure theory, since the cost of financing, generally the company will consider profit retained first, followed by the debt financing, the last consideration should be equity financing. However, because of the incomplete financial system and the restriction policy made by government, the real estate companies cannot financing in a regular order. Every estate listed company which can get the approval to seasoned equity offering often vigorously raise the scale of seasoned equity offering, even raised far more than the demand for funds, in case of need in the future. Such excessive financing behavior will affect the capital usage efficiency of real estate listed company in short term and has an impact on capital structure in the long term, which will reduce the company's performance.

The study of the correlation between seasoned equity offering and company performance of real estate listed companies is of significance. there are some differences in financing behavior directed by the capital structure theory, different study tend to give different conclusions. This article presents a model of the capital structure theory.

\section{Theoretical hypothesis}

\subsection{Financing scale}

In recent years, Chinese real estate industry of China gets a rapid development with an increasing house price. Under this background, the real estate companies can get considerable profits through increasing the investment of commercial house. Getting more capital from seasoned equity offering 
can not only provide stable cash flow to the project which have been invested, but also provide resource to more large-scale projects. Therefore, the following hypothesis is put forward.

Hypothesis 1:

The company performance of real estate listed company after seasoned equity offering is positively related to the scale of seasoned equity offering.

\subsection{Cash balance}

After financing, the real estate listed companies will keep large cash balance if they cannot take advantage of the money into the real estate project seasonably. A large cash balance often indicates a low efficiency of funds or excessive financing, company probably has a bad performance with it. Therefore, the following hypothesis is put forward.

Hypothesis 2:

The company performance of real estate listed company after seasoned equity offering is negatively related to the company cash balance after seasoned equity offering.

\subsection{Asset-liability ratio}

For real estate companies, seasoned equity offering will change its capital structure and financial leverage. In a fast-developing industry, higher proportion of debt financing will simulate the company higher a better performance and higher economic value added. The real estate companies should keep a proper combination of debt and equity financing and capital structure. Therefore, the following hypothesis is put forward.

Hypothesis 3:

The company performance of real estate listed company after seasoned equity offering is positively related to asset-liability ratio after seasoned equity offering.

\subsection{Shareholding structure}

According to the corporate control theory, the equity structure of listed company tends to affect the behavior of the shareholders, further affect the company's performance. An important way for major shareholders to harm small shareholders is conveying benefits illegally to related party. When the proportion of the major shareholders is large enough that major shareholders can only get little benefit from conveying benefits, they will have more motivation to operate company well with better performance than harm small shareholders from conveying benefits, especially in the industry developing fast. Therefore, the following hypothesis is put forward.

Hypothesis 4:

The company performance of real estate listed company after seasoned equity offering is positively related to shareholding ratio of the major shareholders.

\section{Research design and sample selection}

This article mainly studies impact of financing scale, cash balance, capital structure, share structure on the company performance of real estate listed company after seasoned equity offering. There are huge differences in absolute amount in financing scale and cash balance since the different size of companies. We choose the proportion of funds from seasoned equity offering to net asset before financing, the proportion of cash and cash equivalents to total asset in the year of financing, asset-liability ratio in the year of seasoned equity offering, the shareholding ratio of top 10 shareholders after financing as our study index., using simple linear regression and multiple linear regression models to analyze the correlation in three years after seasoned equity offering. In each year, we establish the linear regression and multiple linear regression independently. We use Robust standard error method for heteroscedasticity and delete the variables for multicollinearity. Following is the model:

$$
\begin{aligned}
& \text { roe }_{\mathrm{s}}=\beta_{0}+\beta_{1} \text { scale }+\varepsilon \\
& \text { roe }_{\mathrm{s}}=\beta_{0}+\beta_{2} \mathrm{cash}+\varepsilon
\end{aligned}
$$




$$
\begin{gathered}
\operatorname{roe}_{\mathrm{s}}=\beta_{0}+\beta_{3} \mathrm{dta}+\varepsilon \\
\operatorname{roe}_{\mathrm{s}}=\beta_{0}+\beta_{4} \text { top } 10+\varepsilon \\
\operatorname{roe}_{\mathrm{s}}=\beta_{0}+\beta_{1} \text { scale }+\beta_{2} \mathrm{cash}+\beta_{3} \mathrm{dta}+\beta_{4} \text { top } 10+\varepsilon
\end{gathered}
$$

Since the financial data in three after seasoned equity offering is need, also consider about the new policy of stock issue was published on 2006. We select the real estate listed companies which proceed seasoned equity offering in 2006 2013 as the samples. The following samples will be weeded up:

1. Companies which issue is listed on any foreign stork market..

2. Companies which had equity financing more than one time in the research period.

3. Companies which was listed after 2006 or delisted before 2015.

4. Companies which changed primary business in the research period.

5. Companies which had a negative asset in the research period.

\section{Empirical results}

The simple linear regression and multiple linear regression are established independently for each year, following is the result. The heteroscedasticity has been adjusted and the specific variables have been deleted to weeded out to weed the multicollinearity in multiple linear regression.

\subsection{Simple linear regression result}

The result of simple linear regression

The year of seasoned equity offering

\begin{tabular}{ccccccc}
\hline & $\begin{array}{c}\text { correlation } \\
\text { coefficient }\end{array}$ & $\begin{array}{c}\text { T } \\
\text { value }\end{array}$ & $\begin{array}{c}\text { concomitant } \\
\text { probability }\end{array}$ & $\begin{array}{c}\text { significance } \\
\text { level }\end{array}$ & $\begin{array}{c}\text { whether } \\
\text { heteroscedasticity }\end{array}$ & $\begin{array}{c}\text { adjusted } \\
\mathbf{R}^{\mathbf{2}}\end{array}$ \\
\hline scale & 10.84 & 2.37 & 0.0221 & $5 \%$ & not & 0.09 \\
cash & -49.47 & -1.86 & 0.6851 & not significant & not & 0.05 \\
dta & 0.58 & 3.35 & 0.0016 & $5 \%$ & adjusted & 0.17 \\
top10 & 0.58 & 2.42 & 0.0191 & $5 \%$ & not & 0.09 \\
\hline
\end{tabular}

The second year after seasoned equity offering

\begin{tabular}{ccccccc}
\hline & $\begin{array}{c}\text { correlation } \\
\text { coefficient }\end{array}$ & $\begin{array}{c}\text { T } \\
\text { value }\end{array}$ & $\begin{array}{c}\text { concomitant } \\
\text { Probability }\end{array}$ & $\begin{array}{c}\text { significance } \\
\text { level }\end{array}$ & $\begin{array}{c}\text { whether } \\
\text { heteroscedasticity }\end{array}$ & $\begin{array}{c}\text { adjusted } \\
\mathbf{R}^{\mathbf{2}}\end{array}$ \\
\hline scale & 8.63 & 3.38 & 0.0015 & $5 \%$ & not & 0.18 \\
cash & -37.41 & -2.46 & 0.0176 & $5 \%$ & not & 0.09 \\
dta & 0.52 & 6.14 & 0.0000 & $1 \%$ & not & 0.43 \\
top10 & 0.25 & 1.74 & 0.0880 & $10 \%$ & not & 0.04 \\
\hline
\end{tabular}

The third year after seasoned equity offering

\begin{tabular}{ccccccc}
\hline & $\begin{array}{c}\text { correlation } \\
\text { coefficient }\end{array}$ & $\begin{array}{c}\text { T } \\
\text { value }\end{array}$ & $\begin{array}{c}\text { concomitant } \\
\text { Probability }\end{array}$ & $\begin{array}{c}\text { significance } \\
\text { level }\end{array}$ & $\begin{array}{c}\text { whether } \\
\text { heteroscedasticity }\end{array}$ & $\begin{array}{c}\text { adjusted } \\
\mathbf{R}^{\mathbf{2}}\end{array}$ \\
\hline scale & 3.15 & 1.09 & 0.2813 & not significant & not & 0.00 \\
cash & -22.61 & -1.39 & 0.1723 & not significant & not & 0.02 \\
dta & 0.42 & 4.20 & 0.0001 & $1 \%$ & not & 0.25 \\
top10 & 0.23 & 1.52 & 0.1358 & not significant & not & 0.03 \\
\hline \hline
\end{tabular}


4.2 Multiple linear regression result

\begin{tabular}{|c|c|c|c|c|}
\hline \multicolumn{5}{|c|}{ The result of multiple linear regression } \\
\hline \multicolumn{5}{|c|}{ The year of seasoned equity offering } \\
\hline & $\begin{array}{l}\text { correlation } \\
\text { coefficient }\end{array}$ & T value & $\begin{array}{l}\text { concomitant } \\
\text { Probability }\end{array}$ & significance level \\
\hline dta & 0.56 & 2.77 & 0.0079 & $1 \%$ \\
\hline top10 & 0.55 & 3.08 & 0.0035 & $5 \%$ \\
\hline & $\begin{array}{r}\text { concomitant Pro } \\
\text { Adjusted } \\
\text { whether hetero } \\
\end{array}$ & ty of $F$ & & $\begin{array}{c}0.0004 \\
0.255 \\
\text { adjusted } \\
\end{array}$ \\
\hline \multicolumn{5}{|c|}{ The second year after seasoned equity offering } \\
\hline & $\begin{array}{c}\text { correlation } \\
\text { coefficient }\end{array}$ & T value & $\begin{array}{l}\text { concomitant } \\
\text { Probability }\end{array}$ & significance level \\
\hline dta & 0.46 & 4.00 & 0.0002 & $1 \%$ \\
\hline scale & 5.52 & 2.13 & 0.0387 & $5 \%$ \\
\hline & $\begin{array}{r}\text { concomitant Pro } \\
\text { Adjusted } \\
\text { whether heteros }\end{array}$ & $\begin{array}{l}\text { ty of } F \\
\text { ticity }\end{array}$ & & $\begin{array}{c}0.0000 \\
0.49 \\
\text { adjusted }\end{array}$ \\
\hline \multicolumn{5}{|c|}{ The third year after seasoned equity offering } \\
\hline & $\begin{array}{c}\text { correlation } \\
\text { coefficient }\end{array}$ & T value & $\begin{array}{l}\text { concomitant } \\
\text { Probability } \\
\end{array}$ & significance level \\
\hline dta & 0.42 & 4.20 & 0.0001 & $1 \%$ \\
\hline & $\begin{array}{r}\text { concomitant Pro } \\
\text { Adjustec } \\
\text { whether heteros }\end{array}$ & ty of $F$ & & $\begin{array}{c}0.0001 \\
0.25 \\
\text { not }\end{array}$ \\
\hline
\end{tabular}

Table 2 multiple linear regression result

\subsection{Empirical conclusions}

According to simple linear regression, financing scale, asset-liability ratio, shareholding ratio of top 10 shareholders has positive impact on the company performance of real estate listed company at the year of seasoned equity offering. On the second year, financing scale, asset-liability ratio impact positively on the company performance while the cash balance has a negative impact, the financing scale and asset-liability ratio index has a higher adjusted $\mathrm{R}^{2}$ and has more significant impact. On the third year, only asset-liability ratio has significant correlation with the company performance of real estate listed company. According to the multiple linear regression, all the index have a most powerful in explaining the company performance totally, and asset-liability ratio has significant correlation with the company performance in all three years.

\section{Conclusions}

Theoretical and empirical analysis indicate the factors of the seasoned equity offering have impact on the company performance of real estate listed company after seasoned equity offering, the influence of each factor is various over time. 
1. Linear regression indicate financing scale and cash balance significantly correlate to company performance of real estate listed company on the year of second year after seasoned equity offering and second year after seasoned equity offering, on the third year, there is no correlation between them. The funds got from seasoned equity offering can be used for real estate project, however, once the project accomplished, subsequent operations is uncertain. If the real estate listed company procced excessive financing and cannot take advantage of the funds efficiently, company performance will be reduced. The real estate listed company should consider seriously about the financing demand and the efficiency of funds in the seasoned equity offering, determinate a reasonable scale of financing.

2. Both simple linear regression and multiple linear regression indicate that capital structure has a stable impact on the company performance of real estate listed company after seasoned equity offering. The asset-liability ratio has a deep impact on the company performance according to capital structure theory. The real estate listed companies should have a comprehensive consideration on both short range and long-term interest, especially the long term interest which can be influenced by capital structure. In addition, shareholding ratio of the major shareholders also has some influence on the company performance of real estate listed company after seasoned equity offering.

\section{References}

[1] Yue Feng: Analysis of the Impact of China's Listed Companies Debt Financing on the Company's Performance. ICSREI Vol.10(2013)

[2] Gao, Yan-ru, Lan, Hui, Liang Liang: Relations with nonfinancial listed companies financing structure and corporate performance(2014).

[3] Sanford J. Grossman. The Cost and benefits of Ownership: a Theory of Vertical and Lateral Integration. Journal of Political Economy vol.94(1986), p.1-2.

[4] Hertzel Michael G. Michael Lemmon and James Linck et al, Long-Run performance following private placements of equity, Journal of Finance, (2002).

[5] Wruck W. Networks: Regulating Self-Renewal and Pluripotency. Human Embryonic Stem Cells. Stem Cells(2007).

[6] Zhengfei LU, Yu Xin: The empirical study of main factors that influence the capital structure of listed companies. Journal of accounting research Vol 8(1998).

[7] Jin Li: Study of equity financing performance of listed companies in China. Unpublished $\mathrm{PhD}$ design,(2009).

[8] Haixia Zhang: The performance evaluation of real estate listed companies based on EVA: take poly real estate for instance. Journal of accounting monthly Vol 9(2015). 